\title{
Kamu Kurumlarında Personel Güçlendirme ve İtibar Yönetimi Algısı Arasındaki İlişkinin İncelenmesi: Karaman İli Örneği
}

\author{
Aykut BEDÜK* \\ Mehmet Ali CANBOLAT $* * \bullet$
}

Öz

Karaman ili kamu kurumlarında çalı̧an personelin itibar yönetimi ve personel güçlendirme algıları arasındaki ilişkinin belirlenmesi amacıyla planlanan bu araştırma 287 kamu personeli ile gerçekleştirilmiştir. Araştırmada veri toplama formu olarak demografik bilgileri içeren 6 soru, itibar yönetimi ölçeği (20 soru) ve personel güçlendirme ölçeği (24 soru) kullanılmıştır. Elde edilen verilerin yorumlanması için SPSS21 programında sayı, yüzde, ortalama, standart sapma, en küçük, en büyük değerler gibi tanımlayıcı istatistiklerden yararlanılmıştır. Yine veriler ANOVA, Kruskall Wallis, T testi, Korelasyon analizleri ile değerlendirilmiş, ileri düzey analizler için de Bonferroni testi kullanılmıştır. Araştırma bulgularına göre itibar katsayısı ve personel güçlendirme değişkenleri arasında pozitif yönde anlamlı ilişki bulunduğu belirlenmiştir. Sonuç olarak; itibar katsayısı ölçeğinden alınan puanların eğitim durumu, kadro türü ve medeni durum değişkenlerinden etkilendiği, personel güçlendirme ölçeğinden alınan puanların çalışılan kurumdan etkilendiği anlaşılmıştır. Ayrıca, her iki ölçekten alınan puanların cinsiyet, yaş ve iş tecrübesi değişkenlerinden etkilenmediği tespit edilmiştir.

Anahtar Kelimeler: Personel Güçlendirme, Kurumsal İtibar, İtibar yönetimi, Kamu çalışanları. Jel Kodları : M10, M12

\section{The Research on the Perception of Employee Empowerment and Reputation Management in Public Institutions: The Karaman Province Example}

\footnotetext{
Abstract

This research, which was planned as a descriptive, relation seeker survey in cross-section all type, was applied on 287 public employees in order to determine there potation management and employee empowerment perception on the employees who were working in Karaman provincial directorates. In the study, 6 questions including demographic information, reputation management scale (20 questions) and employee empowerment scale (24 questions) were used as data collection form. In the SPSS21 program, descriptive statistics such as number, percentage, average, standard deviation, minimum and maximum values were used to interpret the obtained data. Again, the data were

* Prof.Dr., Selçuk Üniversitesi, İIBB, Yönetim ve Organizasyon Bölümü, ORCID ID: 0000-0002-0845-8978 abeduk@selcuk.edu.tr

(c) Sorumlu yazar

** Öğr.Gör., Karamanoğlu Mehmetbey Üniversitesi, SBMYO, Yönetim ve Organizasyon Bölümü, 
evaluated with ANOVA, Kruskall Wallis, T test, Correlation analyzes and Bonferroni test was used for advanced analysis. It has been determined that there was a positive and meaningful correlation between there reputation quotient and employee empowerment variables. As a result; it has been found that the scores obtained from the scale of reputation quotient have been influenced by the educational status, type of staff and marital status, and the scores obtained from the employee empowerment scale have been affected by the institution. In addition, it was found that the scores obtained from both scales were not affected by the variables of gender, age and work experience.

Keywords: Empowerment, Reputation, Corporate Reputation, Reputation Management, Public Employees.

Jel Codes : M10, M12

\section{GíRIş}

Günümüz örgütlerinde rekabet avantajı sağlamak adına en önemli unsurlardan birisi olan maliyetleri en az seviyeye indirgemek seçeneği artık tek başına yeterli bir ölçüt değildir. Bilgi ve iletişim teknolojilerinde yaşanan baş döndürücü gelişmeler, beşeri sermayeye yatırım yapmanın ve paydaşların örgütler hakkındaki olumlu algılarının önemini gün geçtikçe daha çok ön plana çıkarmaktadır. Bu noktada beşeri sermaye yatırımlarında personel güçlendirme kavramı ve olumlu örgütsel algı olarak kurumsal itibar kavramları karşımıza çımaktadır. İlk olarak özel sektörün dikkatini çeken bu kavramlardan günümüzde kamu kurumlarında da sıkça bahsedilmeye başlanmıştır (Boon, vd., 2019: 16, Owens, ve Wohlfarth, 2019: 187, Arslan ve Karacaoğlu, 2018: 14, Butler vd., 2018: 1, Bayram vd., 2016: 252, Çınaroğlu ve Şahin, 2013: 293, Işık vd., 2016: 177).

Personel güçlendirme kavramı ile ilgili literatürde çeşitli tanımlar bulunmaktadır. Likert (1961, 1967) personel güçlendirmeyi üstlerin yetki ve güçlerini astları ile paylaşmaları şeklinde değerlendirmiştir (Aktaran: Ertenü, 2008: 15). Personel güçlendirme kavramı günümüzdeki anlamına ise ancak 1980'lerin sonunda ulaşabilmiş̧ir (Tekin ve Köksal, 2012: 4243). Buna göre personel güçlendirme; astların, organizasyon yönünü ve performansını etkileyen kararlar verebilme yetkisi (Bowen ve Lawler, 1992: 32), bilgi, performans sonucu elde edilecek kazanım ve gücün astlarla paylaşılması (Hales ve Klidas, 1998: 89), astların tutumlarının yeniden yapılandırılması yoluyla kişisel başarıya ulaşmak için karar verme yetkisine henüz sahip olmayan kişilere karar verme yetkisinin devredilmesi (Cunningham vd.,1996: 144), astlarla gücü paylaşma ve en azından bazı kararları alma ve uygulama yetkisi verme olarak tanımlanabilir (Griffin vd., 2015: 469). Buradan hareketle personel güçlendirme, açık bir sistem ya da kural olmamakla birlikte astların eyleme geçerken kendi kararlarını verebilmesi (Pradhan vd.,2014: 61), daha ziyade inisiyatif kullanma güdüsünün herhangi bir tedirginlik duyulmadan ihtiyaç duyulduğunda açığa çıkabilmesidir. Özetle personel güçlendirme; işgörenlerin işlerini daha etkin bir biçimde yapmaları için kendilerine olan güvenlerini geliştiren ve kendi katkılarının örgütün performansına direkt olarak etki ettiğine inanan işgörenler ile gücün, yetkinin ve sorumluluğun paylaşılması sürecidir (Akçakaya, 2010: 168). 
Personel güçlendirme sürecinde ilk olarak kendini güçsüz hisseden astların güç ihtiyacı karşımıza çıkmaktadır. Bu nedenle astları arasında güçsüzlük duygusunu besleyen örgütler ancak yetkilendirme stratejileri ile bu güçsüzlük duygusunu ortadan kaldırabileceklerdir (Conger ve Kanungo, 1988: 474). Temel olarak, güçlendirme iki şey gerektirir: Bunlar üstlerin (Griffin vd., 2015: 470); astların çalışmalarında, daha fazla güç ve kontrol sahibi olmalarına izin vermesi veastlara yetkilendirilmiş hareket etme becerilerini ve özgüvenlerini vermek için eğitim, kaynak ve koçluk sağlamasından ibarettir.

Personel güçlendirme olgusu çalışanların psikolojik hislerine eğilir (Chang ve Liu, 2007: 1442). Dolayısıyla personel güçlendirme faaliyetleri sonucunda işgören işini daha çok benimseyerek işindeki başarısı için daha fazla gayret gösterecektir (Pelit, 2011: 210). Personel güçlendirme örgütün astlarını ilgilendiren bir süreçtir. Bu sürecin başarıya ulaşması ise astların gönüllü ve istekli olarak uygulamaya katılımlarına bağlıdır (Öksüz, 2010: 38). Nitekim güvenilir işgörenlere kendi çalışmalarını yönetme ve işlerini yürütme gücü verildiğinde aslında personel güçlendirme de sağlanmış olacaktır (Şenel, 2006: 2).

Personel güçlendirme faaliyetlerine verilen önem, aynı zamanda itibar yönetimlerini de olumlu yönde etkilemektedir (Bedük ve Tambay, 2014: 335). Günümüzde kurumsal itibarın önemsiz bir konu olduğunu iddia etmek mümkün değildir (Barnett vd.,2006: 35) ve bu bilinçle 1990'lardan itibaren kurumsal itibar çalışmalarında hızlı bir artış kaydedilmiştir (Martin ve Hetrick, 2006: 21). Özellikle kamuoyu üzerinde oluşturulan etki, algı ve çağrışımlar örgütün kurumsal itibarının oluşmasında öncü kavramlar olarak karşımıza çıkarlar (Karatepe, 2008: 92). Son yıllarda itibar araştırmalarında kaydedilen ilerlemeye rağmen, ortak bir tanım bulunmamaktadır. Eğilmez (2017: 133) bilimsel araştırmasındaki katılımcıların; "saygınlık ve güvenilirlik" kavramlarını "itibar" kavramı ile eșdeğer tuttuklarını ileri sürmüştür. Tokatlı (2015: 150)'ın araștırmasında ise kurumsal itibar kavramı; katılımcılar tarafından çoğunlukla "güvenilir olma" olarak tanımlanmıştır (Tokatlı, 2015: 150). Özetle; kurumsal itibar, örgüt paydaşlarının örgütle ilgili belirli bir süre zarfında oluşan tüm yargılarının toplamı (Ergenç, 2010: 8) ve örgütler için rekabet avantajı yaratan stratejik bir kaynak olarak karşımıza çıkar (Abratt ve Kleyn, 2012: 1059). Olumlu şekilde algılanan bir itibar, kurumu zirveye taşıyabileceği gibi olumsuz olarak algılanan bir itibar da kurumu sektördeki yerinden uzaklaştırabilmektedir (Yurt, 2012: 74).

Türk ve Güven (2007: 89), bir örgütte görülen ve görülmeyen varlıkların bulunduğunu: Görünen varlıkların; gelirler, giderler, kar, zarar, demirbaşlar, yatırımlar, ücretler, primler, ikramiyeler ve çalışanlar olduğunu ve görülemeyenlerin ise; saygınlık, prestij ve güvenilirlik olduğunu ifade etmişlerdir. Kurumsal itibar; örgütlerin zamanla biriktirdikleri ve içsel olarak geliştikleri (Wang vd.,2016: 1330) ve o örgütün paydaşları tarafından nasıl algılandığını gösteren soyut bir varlıktır (Bedük, 2012: 108-109). Rakipler örgütlerin somut yeteneklerini çabucak taklit edebilirken soyut yeteneklerini taklit etmeleri bir hayli zaman almaktadır. Bu sebeple kurumsal itibar oluşturulması gibi soyut yeteneklere yönelmek rekabet avantajı sağlanması için hayati öneme sahip bir konu haline gelmiştir (Yağcioğlu, 2012: 7). Ancak soyut bir kavram olan kurumsal itibar, oluşum sürecini 
başarıyla tamamladığında -örneğin, örgütün pazardaki konumunun tespiti gibi- artık karşımıza somut bir kavram olarak çıkacaktır (Usta, 2006: 36).

Gelişen kurumsal itibar literatürünün, yetenekleri kendine çekmek ve elinde tutmak ve tüm paydaşlarla ayakta durmalarını optimize etmekle ilgilenen örgütlere sunacağı birçok yararı bulunmaktadır (Highhouse vd.,2009: 1489). Zira kurumsal itibar, çeşitli paydaşların bir örgüte karşı çalışanların elde tutulması ve müşteri sadakati ya da müşteri memnuniyeti gibi davranışlarını etkilemektedir (Chun, 2005: 91). Kurumsal itibarı bir rekabet avantajı kaynağı olarak kullanmak için örgütün paydaş algılarını değiştirmesi adına yeteneklerini ve eylemlerini sergilemesi gerekir (Dowling ve Moran, 2012: 28). Keza bir örgütün farklı paydaş gruplarına mensup bireylerin, o örgütün kurumsal itibarı hakkında benzer izlenimlere sahip olduğu yadsınamaz bir gerçektir (Helm, 2007: 244).

Kurumsal itibarın rekabetçi bir silah olarak faydalı olması için, örgütün kimliği ve davranışının düzenli olarak kabul görmesi gerekmektedir (Dowling, 2004: 23). Çünkü kurumsal itibarın yapı taşları kurumsal kimlik ve kurumsal imajdır (Köksal, 2011: 16). Kurumsal itibar; kurumsal kimlik, imaj, iletişim ve kurumsal kültürden oluşmakla birlikte itibar kavramı sık sık bu kavramlarla karıştırılmaktadır. Ancak yazında, her bir kavram itibarın birer unsuru olarak ele alınmaktadır ve birbirlerinden ayrı düşünülemezler. (Güneş, 2016: 6).

Literatür incelendiğinde Fombrun vd. (2000: 253)'nin geliştirdikleri itibar katsayısı ölçeğinde kurumsal itibarın; duygusal çekicilik, ürün ve hizmetler, vizyon ve liderlik, işyeri çevresi, sosyal ve çevresel sorumluluk, finansal performans olmak üzere altı boyutunun bulunduğunu tespit etmişlerdir.

Men ve Stacks (2013: 171) liderlik tarzı ve personel güçlendirmenin algılanan kurumsal itibara olan etkisini araştırdıkları çalışmalarında; işgörenlerin örgüte yönelik görüşlerini belirleyen temel unsurun, işgörenlerin nasıl muamele gördükleri ve karar verme konusunda ne kadar söz sahibi olduklarına göre belirledikleri yönünde oluştuğunu ortaya koymuşlardır. Çözüm önerisi olarak da olumlu bir kurumsal itibar oluşturulması adına iletişim profesyonellerinden yardım alınması gerektiğini savunmuşlardır.

Gössling vd. (2019: 1744, 1757)'nin beş farklı ülke ve 270 konaklama işletmesi ile gerçekleştirdiği araştırmalarında artan rekabet koşullarında yeni müşterilerin web üzerinden konaklama rezervasyonu yaparken eski müşterilerin konaklama puanı ve yorumlarına dikkat ettiğini, müşterilerin konaklama işletmesini rakip işletmelerle rahatlıkla kıyaslayabildiğini ve müşterilerin olumsuz yorumlardan etkilendiği noktasından hareketle kurumsal itibarın önemini ortaya koymaya çalışmışlardır. Sonuç olarak müşteri kaybının önlenmesi için kurumsal itibar oluşturulmasına yönelik stratejiler geliştirilmesi gerektiğini önermişlerdir.

Christensen vd. (2018: 6) ise bir üniversitenin kurumsal itibarını oluştururken izlemesi gereken temel yolun o üniversitenin geçmişi, kaynakları, yeterlilikleri ve çıktılarını ön 
planda tutmasından geçtiğini savunmuşlardır.

Yüce ve Taşdemir (2018: 1195) araştırmalarında sosyal medyayı kurumsal itibar oluşturmak adına kullanan örgütlerin; sosyal medyayı itibar yönetiminde belirli bileşenler için aktif bir şekilde kullanmalarına karşın belirli bileşenler için hiçbir paylaşımda bulunmadıklarını tespit etmişlerdir. Araştırma kapsamına alınan örgütlerin kimileri kurumsal itibarın "vizyon ve liderlik" boyutuna önem verirken kimileri ise sadece "duygusal çekicilik" boyutuna önem verebilmektedir. Öte yandan Kızıl ve Naktiyok (2019: 64) yine kurumsal itibarın "sosyal sorumluluk" bileşeninin stratejik liderlik ve kurumsal itibar arasındaki ilişkide kısmi aracılık rolünün bulunduğunu tespit etmişlerdir. Kurtuluş (2018: 92) ise araştırmasında kıdemli işgörenlerin kıdemsiz işgörenlere nazaran kurumsal itibar algılarının daha yüksek olduğunu tespit etmiştir.

Bütün bu sonuçlardan hareketle kurumsal itibarın tüm bileşenleri ile birlikte değerlendirilmesi gerektiği açıktır. Araştırma sonuçları kurumsal itibarın önemini ortaya koyar niteliktedir. Öte yandan gerek itibar yönetimi gerekse personel güçlendirme konusunda kamu kurumlarında yapılan araştırmalar incelendiğinde genellikle tek bir kurum üzerinde araştırma yapıldığı görülmüştür. Oysa bir ilin genelini kapsayan bir araştırma daha kesin sonuçlar verebilecektir. Bu bağlamda çalışmamız Karaman Valiliği ve bağlı 6 il müdürlüğünde çalışan kamu personelinin itibar yönetimi ve personel güçlendirme algılarının belirlenmesi amacıyla planlanmıştır. İlk olarak giriş bölümünde kavramsal çerçeve incelenmiş, ikinci bölümde araştırmanın yöntemine değinilmiş, üçüncü bölümde bulgular tespit edilmiş ve son bölümde ise araştırma bulguları tartışılarak bir takım sonuçlara ulaşılmıştır. Araştırmanın, bir ilin genelini kapsaması bakımından literatüre katkı sağlayacağı düşünülmektedir.

\section{YÖNTEM}

\subsection{Araştırmanın Tipi}

Araştırma, Karaman Valiliği ve bağlı il müdürlüklerinde çalışan personelin itibar yönetimi ve personel güçlendirme algılarının belirlenmesi amacıyla belirli bir zaman dilimi aralığında gerçekleştirildiğinden kesitsel tipte, tanımlayıcı istatistik yöntemleri kullanılması ile değişkenler arasında ilişki arayıcıyı olarak planlanmıştır.

\subsection{Araştırmanın Soruları}

$S_{1}:$ Katılımcıların demografik özellikleri itibar yönetimi algılarını etkiler mi?

$\mathrm{S}_{2}$ : Katılımcıların demografik özellikleri personel güçlendirme algılarını etkiler mi?

$\mathrm{S}_{3}$ : Katılımcıların itibar yönetimi algıları ile personel güçlendirme algıları birbirini etkiler mi? 


\subsection{Araştırmanın Evren ve Örneklemi}

Araştırma, Karaman Valiliğine bağlı il müdürlüklerinde (SGK, Tarım İl Müdürlüğü, Nüfus İl Müdürlüğü, Tapu İl Müdürlügüu, Kadastro İl Müdürlüğü, Valilik iç birimleri ve İŞKUR) çalışan kadrolu memurlarla yürütülmüştür. İl Emniyet Müdürlüğü yoğunluğundan ötürü, İl Afet Müdürlüğü ve Müze Müdürlüğü gibi kurumlar ise çalışan sayılarının çok az olmasından ötürü araştırmaya dahil edilmemiştir. Örneklem hesabı yapılmamış, araştırmaya katılmaya gönüllü ve veri toplama tarihleri arasında aktif olarak çalışan tüm personel araştırma kapsamına alınmıştır. Buna göre kurumlarda çalışan sayısı, geçerli anket sayısı ve ankete dönüş oranları Tablo 1'de verilmiştir.

\section{Tablo 1. Kurumlarda Çalışan Sayısı, Geçerli Anket Sayısı ve Ankete Dönüş Oranları}

\begin{tabular}{|c|c|c|c|}
\hline Kurumlar & $\begin{array}{l}\text { Çalışan } \\
\text { Sayısı* }\end{array}$ & $\begin{array}{c}\text { Geçerli Anket } \\
\text { Sayısı }\end{array}$ & $\begin{array}{l}\text { Ankete Dönüiş Oranı } \\
(\%)\end{array}$ \\
\hline Sosyal Güvenlik Kurumu & 78 & 75 & 96 \\
\hline Tarım İl Müdürlüğü & 180 & 129 & 72 \\
\hline Nüfus İl Müdürlüğü & 20 & 17 & 85 \\
\hline Tapu ve Kadastro İl Müdürlüğü & 40 & 13 & 33 \\
\hline Valilik iç birimleri & 50 & 32 & 64 \\
\hline İŞKUR & 30 & 21 & 70 \\
\hline Toplam & 398 & 287 & 72 \\
\hline
\end{tabular}

*Çalışan sayıları il müdürlüklerinin insan kaynakları departmanlarından temin edilmiş olup yaklaşık sonuçlardır.

\subsection{Veri Toplama Formu}

Araştırmada veri toplama formu olarak demografik bilgileri içeren 6 soru, personel güçlendirme ölçeği (24 soru) ve itibar katsayısı ölçeği (20 soru) kullanılmştır.

İtibar Katsayısı Ölçeği: İtibar yönetimi algısını ölçmek için Reputation Institute tarafından hazırlanmış olan "İtibar Katsayısı” ölçeği (Reputation Quotient-R.Q. ${ }^{\circledR}$ ) kullanılmıştır (Fombrun vd.,2000: 253). Ölçek, 1-Kesinlikle Katılmıyorum’dan 5-Tamamen Katılıyorum’a beşli likert tiptedir. Yirmi adet yargı içeren itibar katsayısı ölçeği, kurumsal itibarın duygusal çekicilik, ürün ve hizmetler, vizyon ve liderlik, işyeri çevresi, sosyal ve çevresel sorumluluk, finansal performans şeklinde altı temel bileşenden oluşmaktadır. Çalışmada Alnıç̧ı vd. (2010: 104) tarafından geçerlilik ve güvenilirliği sınanarak Türkçe’ye aktarılan itibar katsayısı ölçeğinden yararlanılmıştır. Ölçek maddeleri üzerinde maddenin anlam bütünlügünnden uzaklaşmadan örneğin; "insanların o işletmeye hayranlık ve saygı duyması" ifadesi yerine "insanlar kurumuma hayranlık ve saygı duyar" şeklinde "kurum" ifadesi eklenerek uyarlama yapılmıştır.Bu sebeple doğrulayıcı faktör analizi uygulanarak 
ölçeğin yeniden geçerlik ve güvenilirliği test edilmiştir. Bu araştırmada chronbach alpha değeri .95 olarak tespit edilmiştir.

Personel Güçlendirme Ölçeği: Ölçek, Özaksu(2006: 118-120) tarafından geliştirmiş ve daha sonra Karahan (2009: 106) tarafından bir kamu hastanesi işgörenleri için yeniden uyarlanarak geçerlilik güvenirliliği sınanmıştır. 1-Kesinlikle Katılmıyorum'dan 5-Tamamen Katılıyorum'a beşli likert tipte olan ölçeğin bu araştırmada chronbach alpha değeri .92 olarak tespit edilmiştir.

\subsection{Verilerin Toplanması}

Veriler, araştırmacılar tarafından geliştirilen anket formu, İtibar Katsayısı Ölçeği ve Personel Güçlendirme Ölçeği ile Ekim-Kasım 2018 tarihleri arasında elde edilmiştir. Anket formu araştırmacılar tarafından yüz yüze görüşme yöntemi ile toplanmıştır. Veri toplama tarihlerinde aktif olarak kurumda çalışan katılımcıların uygun oldukları zamanda veriler toplanmış ve anket formunu doldurmak ortalama $10 \mathrm{dk}$. sürmüştür.

\section{6.İstatistiksel Değerlendirme}

Elde edilen veriler SPSS21 programında sayı, yüzde, ortalama, standart sapma, en küçük, en büyük değerler gibi tanımlayıcı istatistikler ve ANOVA, Kruskall Wallis, T testi, Korelasyon analizleri ile değerlendirilmiştir. İleri analiz için Bonferronitesti kullanılmıştır. Ayrıca itibar katsayısı ölçek maddelerine "kurum" ifadesi eklenerek uyarlama yapıldı̆̆ı için faktör yüklerinin geçerlilik ve güvenirliliğini test etmek adına doğrulayıcı faktör analizi tekniğinden yararlanılmıștır.

\section{BULGULAR}

Katılımcıların demografik özelliklerine ait bulgular Tablo 2'de verilmiştir. Buna göre katılımcıların \%39,4'ü 31-40 yaş arasında, \%72,8'i erkek, \%72,1'i üniversite mezunu, \%84’ü evli, \%33,8’i 20 yıldan uzun süreli iş tecrübesine sahip ve \%47’si genel idari hizmetlerde görev yapmaktadır.

İtibar katsayısı ölçeği boyutlarının desteklenmesi amacı doğrulayıcı faktör analizi uygulanmıştır. Yapısal eşitlik modellemesi kullanılarak itibar katsayısı ölçeğinin boyutlarına uygulanan doğrulayıcı faktör analizi bulguları Şekil 1'de gösterilmiştir. Analiz sonucuna göre boyutların güvenilir olduğu tespit edilmiştir. 


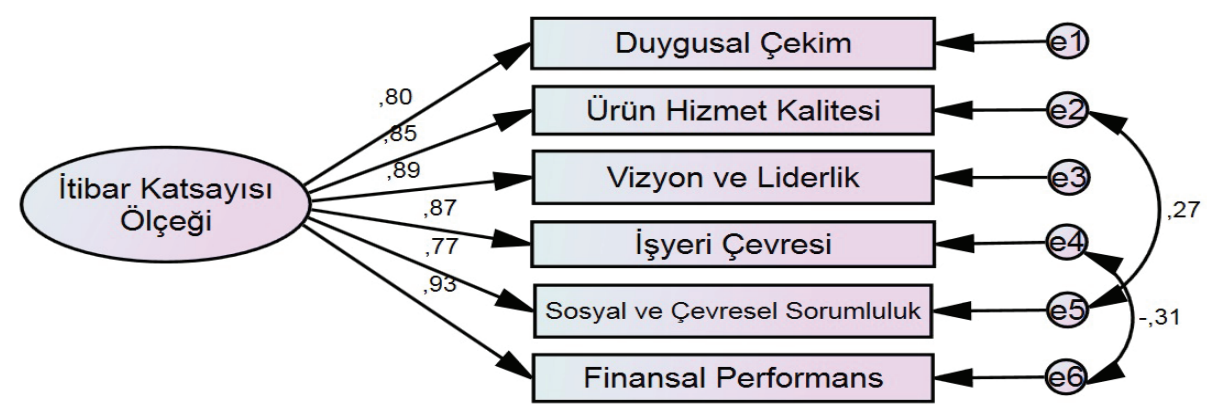

\section{Şekil 1. İtibar Katsayısı Ölçeği Doğrulayıcı Faktör Analizi Sonuçları}

Modelde yer alan değerler standardize edilmiş tahmine ait parametrelerdir. Model X2/ df, IFI, CFI ve RMSEA uyum indeksleri ile test edilmiştir. Yapısal eşitlik modellemesinde önerilen teorik modelin elde edilen verileri ne derece iyi açıkladığını uyum indeksleri ile belirlenirken, uyum iyiliği indeksleri modelin kabul ya da ret edilmesi kararının verilmesinde kullanılmaktadır (Cengiz ve Kırkbir, 2007: 30). Tablo 2'de görüldüğü üzere uyum indeksleri kabul edilebilir sınırlar içerisinde yer almaktadır.

Tablo 2. Araştırma Modeli Uyum İyiliği İndeksleri

\begin{tabular}{lll}
\hline Model Uyum İndeksleri & $\begin{array}{l}\text { Refer a n s } \\
\text { Değerler }\end{array}$ & $\begin{array}{l}\text { Araştırma } \\
\text { Bulguları }\end{array}$ \\
\hline CFI (Karşılaştırmalı Uyum iyiliği indeksi) & $\geq 0,90$ & 0,993 \\
IFI (Artırımlı Uyum İyiliği İndeksi) & $\geq 0,90$ & 0,993 \\
RMSEA (Yaklaşım Hatasının Kök Ortalama Karesi) & $\leq 0,08$ & 0,071 \\
X2 /df & $\leq 3$ & 2,440 \\
\hline
\end{tabular}

Katılımcıların itibar katsayısı toplam/alt boyutlardan ve personel güçlendirme ölçeklerinden aldıkları en küçük en büyük puanlar, ortalama ve standart sapma değerler Tablo 3'de verilmiştir. Buna göre; itibar katsayısı ölçeği toplamından alınan puan

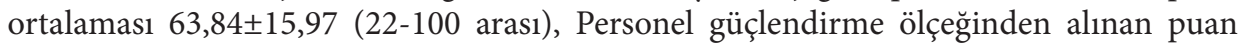
ortalaması 84 $\pm 15,11$ (29-120 arası) idi. Ölçeklerden alınan chronbach alpha değerleri sırasıyla .95 ve .92'dir. İtibar ölçeği alt boyutlarının chronbach alpha değerleri .68 ile .82 arasında değişmektedir.

Tablo 3. Katılımcıların İtibar Katsayısı Toplam/Alt Boyutları ve Personel Güçlendirme Ölçeklerinden Aldıkları En Küçük En Büyük Puanlar, Ortalama ve Standart Sapma Değerler 


\begin{tabular}{lccc}
\hline \multicolumn{1}{c}{ Ölçek/Alt Boyutlar } & $\begin{array}{c}\text { En Küçüik-En Büyük } \\
\text { Değer }\end{array}$ & Ortalama \pm SS & Chronbach \\
\hline İtibar Katsayısı Ölçeği Toplam & $22-100$ & $63,84 \pm 15,97$ & Alpha \\
Duygusal Çekim & $3-15$ & $9,56 \pm 2,73$ & .95 \\
Ürün Hizmet Kalitesi & $4-20$ & $13,53 \pm 3,60$ & .81 \\
Vizyon ve Liderlik & $3-15$ & $8,49 \pm 2,94$ & .82 \\
İşyeri Çevresi & $3-15$ & $9,60 \pm 2,77$ & .74 \\
Sosyal ve Çevresel Sorumluluk & $4-15$ & $10,53 \pm 2,51$ & .68 \\
Finansal Performans & $4-20$ & $12,13 \pm 3,51$ & .76 \\
Personel Güçlendirme Ölçeği & $29-120$ & $84 \pm 15,11$ & .92 \\
\hline
\end{tabular}

Katılımcıların yaş, eğitim durumu, iş tecrübesi ve kadro türleri ile itibar katsayısı toplam/ alt boyut ve personel güçlendirme ölçeklerinden aldıkların puan ortalamalarının karşılaştırmaları Tablo 4'de verilmiştir. Buna göre; ilköğretim mezunlarının diğer mezunlara göre itibar katsayısı ölçeği toplamından, vizyon ve liderlik, işyeri çevresi alt boyutlarından daha yüksek puan ortalamasına sahip olduğu, üniversite mezunlarının duygusal çekim ve finansal performans alt boyutlarından daha düşük puan aldığı ve farkın istatistiksel olarak anlamlı olduğu $(\mathrm{p}<0.05)$ belirlenmiştir. Diğer bir ifade ile istatistiksel olarak ilköğretim mezunlarının diğer mezunlara göre belirlenen boyutlardaki algısının daha düşük olduğu tespit edilmiştir. Genel idari hizmetler kadrosunda olanların diğer kadrolarda çalışanlara oranla itibar katsayısı ölçeği toplamından, duygusal çekim, vizyon ve liderlik, işyeri çevresi, finansal performans alt boyutlarından daha düşük puan ortalamasına sahip oldukları ve farkın istatistiksel olarak anlamlı olduğu $(\mathrm{p}<0.05)$ görülmüştür. Diğer bir ifade olarak istatistiksel olarak genel idari hizmetler kadrosunda çalışanların diğer kadrolarda çalışanlara nazaran ilgili boyutlardaki algısının daha düşük olduğu tespit edilmiştir. Valilik iç birimlerinde çalışanların diğer kurumlarda çalışanlara göre itibar katsayısı ölçeği toplamından, duygusal çekim, vizyon ve liderlik, sosyal ve çevresel sorumluluk, finansal performans alt boyutları ve personel güçlendirme ölçeklerinden daha yüksek puan ortalamasına sahip oldukları, İşKUR'da çalışanların ürün-hizmet kalitesi ve işyeri çevresi alt boyutlarından daha düşük puan ortalamasına sahip oldukları ve farkın istatistiksel olarak anlamlı olduğu görülmüştür $(\mathrm{p}<0.05)$. İtibar katsayısı ölçeği ve personel güçlendirme ölçeklerinden alınan puan ortalamalarının yaş ve iş tecrübesinden etkilenmediği, eğitim durumu ve kadro türünün ise personel güçlendirme ölçeğinden alınan puanları etkilemediği belirlenmiştir ( $>0.05)$.

Tablo 4. Katılımcıların Yaş, Eğitim Durumu, İş Tecrübesi ve Kadro Türleri ile İtibar Katsayısı Toplam/Alt Boyut ve Personel Güçlendirme Ölçeklerinden Aldıkları Puan Ortalamalarının Karşılaştırmaları (N=287) 


\begin{tabular}{|c|c|c|c|c|c|c|}
\hline 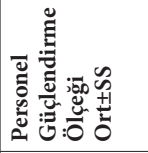 & 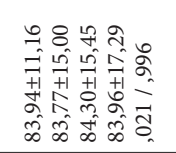 & 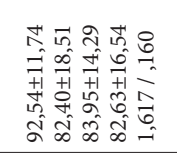 & 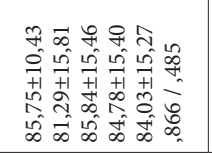 & 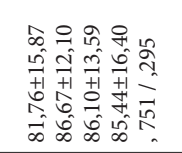 & 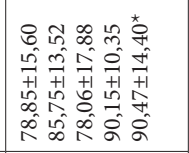 & 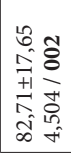 \\
\hline 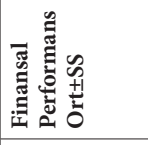 & 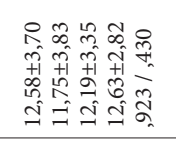 & 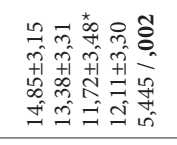 & 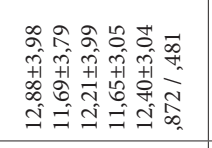 & 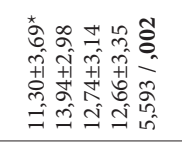 & 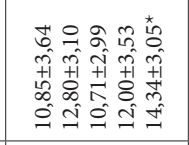 & 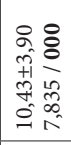 \\
\hline 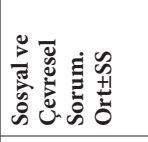 & 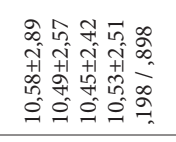 & 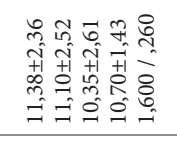 & 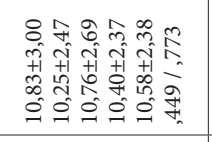 & 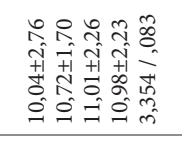 & 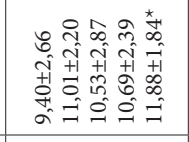 & 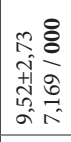 \\
\hline 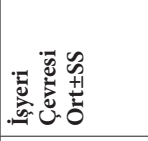 & 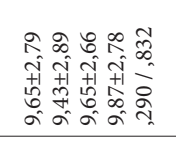 & 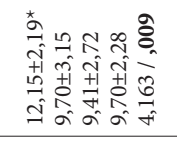 & 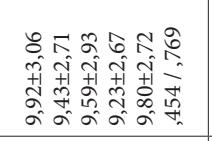 & 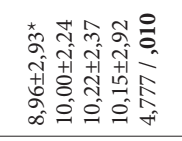 & 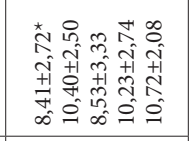 & 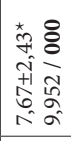 \\
\hline 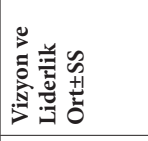 & 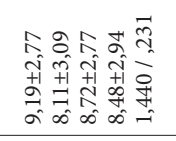 & 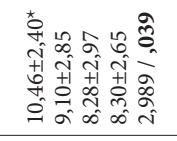 & 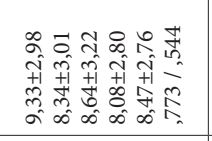 & 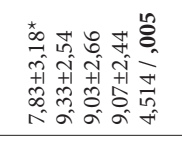 & 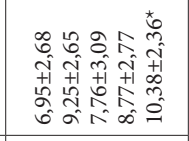 & 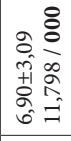 \\
\hline 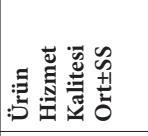 & 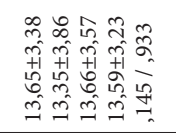 & $\begin{array}{l}\infty \\
\infty \\
\infty\end{array}$ & 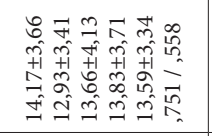 & 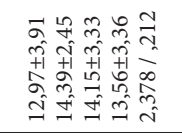 & 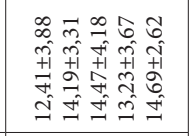 & 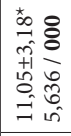 \\
\hline 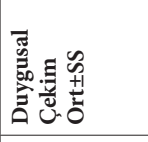 & 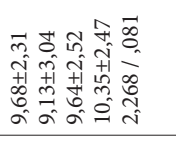 & 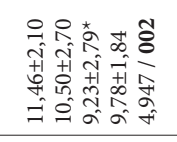 & 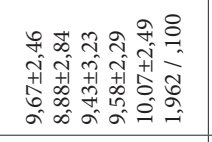 & 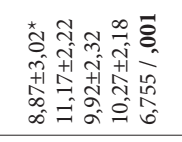 & 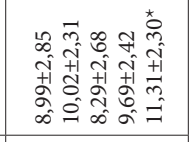 & 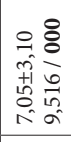 \\
\hline 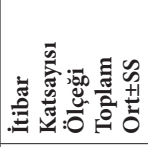 & 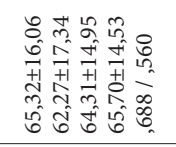 & 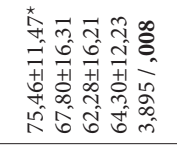 & 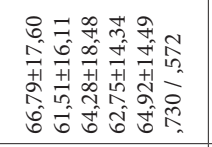 & 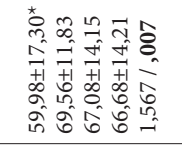 & 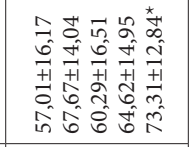 & 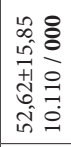 \\
\hline 苞 & 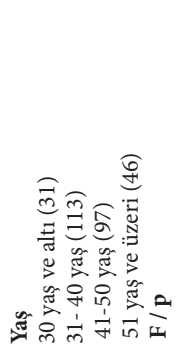 & 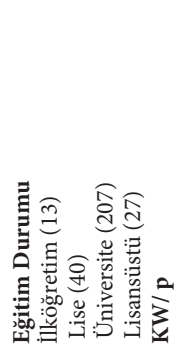 & 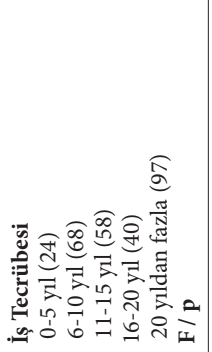 & 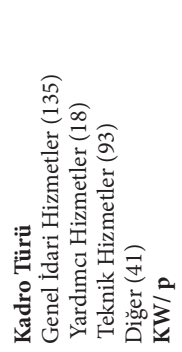 & 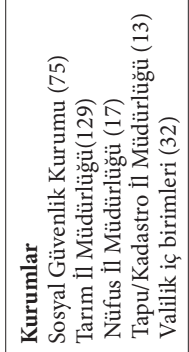 & בิ \\
\hline
\end{tabular}

Tablo 5. Katılımcıların Cinsiyet ve Medeni Durumları ile İtibar Katsayısı Toplam/ Alt Boyut ve Personel Güçlendirme Ölçeklerinden Aldıkları Puan Ortalamalarının Karşılaştırmaları 


\begin{tabular}{|c|c|c|}
\hline 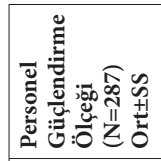 & 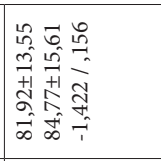 & 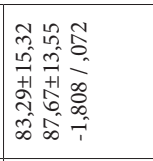 \\
\hline 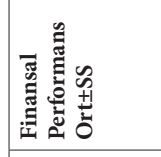 & 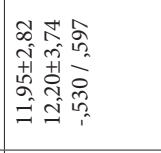 & 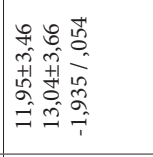 \\
\hline 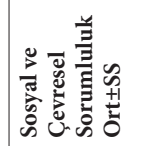 & 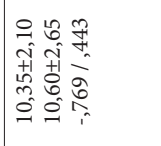 & 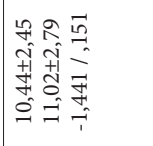 \\
\hline 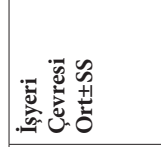 & 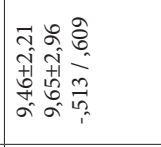 & 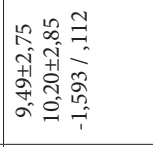 \\
\hline 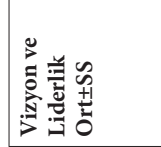 & 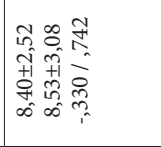 & 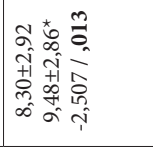 \\
\hline 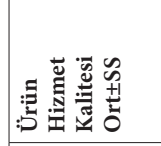 & 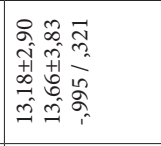 & 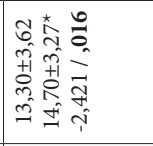 \\
\hline 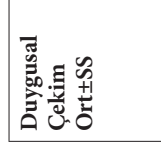 & 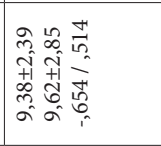 & 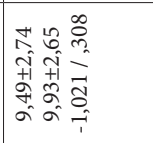 \\
\hline 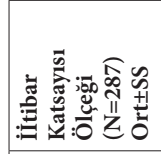 & 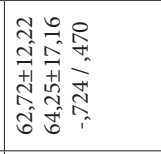 & 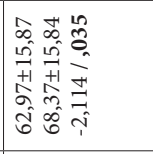 \\
\hline 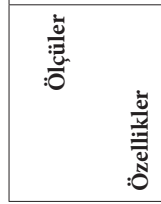 & 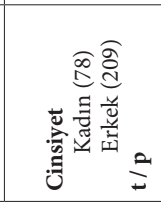 & 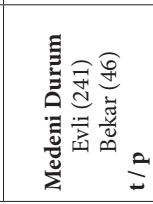 \\
\hline
\end{tabular}

Katılımcıların cinsiyet ve medeni durumları ile itibar katsayısı ve personel güçlendirme ölçeklerinden aldıkların puan ortalamalarının karşılaştırmaları Tablo 5 'te verilmiştir. Buna göre; itibar katsayısı ve personel güçlendirme ölçeğinden alınan puan ortalamalarının cinsiyetten etkilenmediği ( $>0.05$ ), bekarların itibar katsayısı ölçeği toplamı, ürün-hizmet kalitesi, vizyon ve liderlik alt boyutlarından daha yüksek puan ortalamasına sahip olduğu ve farkın istatistiksel olarak anlamlı olduğu $(\mathrm{p}<0.05)$ belirlenmiştir. Medeni durum Personel güçlendirme ölçeğinden alınan puan ortalamalarını etkilememektedir ( $\mathrm{p}>0.05)$. 
Katılımcıların itibar katsayısı ve personel güçlendirme ölçeklerinden aldıkları puan ortalamalarının korelasyonu Tablo 6’ da verilmiştir. Buna göre ölçekler arasında pozitif yönde anlamlı ilişki bulunmuştur. İtibar katsayısı ölçeğinden alınan puanlar yükseldikçe personel güçlendirme ölçeğinden alınan puanlarda yükselmektedir.

\section{Tablo 6. Katılımcıların İtibar Katsayısı ve Personel Güçlendirme Ölçeklerinden Aldıkları Puanların Korelasyonu}

\begin{tabular}{lc}
\hline & İtibar Yönetimi Ölçeği \\
\hline $\begin{array}{l}\text { Personel Güçlendirme Ölçeği } \\
\text { Pearson Korelasyon }\end{array}$ &, 628 \\
$\mathrm{p}$ & $\mathbf{0 0 0}$ \\
\hline
\end{tabular}

\section{TARTIŞMA VE SONUÇ}

Karaman Valiliği ve bağlı il müdürlüklerinde çalışan personelin itibar yönetimi ve personel güçlendirme algılarının belirlenmesi amacıyla planlanan araştırmaya 287 kişi katılmıştır. Araştırma bulgularına göre; katılımcıların \%39,4'ünün 31-40 yaş arasında, \%72,8’inin erkek, \%72,1'inin üniversite mezunu, \%84'ünün evli, \%33,8'inin 20 yıldan uzun süreli iş tecrübesine sahip ve \%47'sinin genel idari hizmetlerde görev yaptığı, katılımcıların

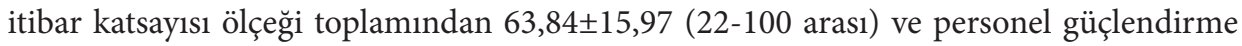

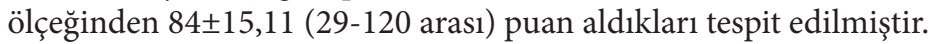

İlk araştırma sorusu " $\mathrm{S}_{1=}$ Katılımcıların demografik özellikleri itibar yönetimi algılarını etkiler mi?” incelendiğinde;

-İtibar katsayısı ölçeğinden alınan puan ortalamalarının yaş, iş tecrübesi ve cinsiyetten etkilenmediği,

-İlköğretim mezunlarının itibar katsayısı ölçeği toplamından, vizyon ve liderlik, işyeri çevresi alt boyutlarından daha yüksek puan ortalamasına sahip olduğu, üniversite mezunlarının duygusal çekim ve finansal performans alt boyutlarından daha düşük puan aldığı ve farkın istatistiksel olarak anlamlı olduğu,

-Genel idari hizmetler kadrosunda olanların itibar katsayısı ölçeği toplamından, duygusal çekim, vizyon ve liderlik, işyeri çevresi, finansal performans alt boyutlarından daha düşük puan ortalamasına sahip oldukları ve farkın istatistiksel olarak anlamlı olduğu,

-Valilik iç birimlerinde çalışanların itibar katsayısı ölçeği toplamından, duygusal çekim, vizyon ve liderlik, sosyal ve çevresel sorumluluk, finansal performans alt boyutlarından daha yüksek puan ortalamasına sahip oldukları, İŞKUR'da çalışanların ürün-hizmet 
kalitesi ve işyeri çevresi alt boyutlarından daha düşük puan ortalamasına sahip oldukları ve farkın istatistiksel olarak anlamlı olduğu,

-Medeni durumu bekar olanların itibar katsayısı ölçeği toplamı, ürün-hizmet kalitesi, vizyon ve liderlik alt boyutlarından daha yüksek puan ortalamasına sahip olduğu ve farkın istatistiksel olarak anlamlı olduğu görülmüştür.

Dolayısı ile yaş, iş tecrübesi ve cinsiyet haricindeki değişkenlerin kamu kurumunda görev yapanların itibar yönetimi algılarını etkilediği sonucuna ulaşılmıştır.

İkinci araştırma sorusu " $\mathrm{S}_{2=}$ Katılımcıların demografik özellikleri personel güçlendirme algılarını etkiler mi?” incelendiğinde;

-Valilik iç birimlerinde çalışanların personel güçlendirme ölçeğinden daha yüksek puan ortalamasına sahip oldukları,

-Personel güçlendirme ölçeğinden alınan puan ortalamalarının yaş, medeni durum, cinsiyet, iş tecrübesi, eğitim durumu ve kadro türünden etkilenmediği sonucuna ulaşılmıştır.

Son olarak üçüncü araştırma sorusu " $\mathrm{S}_{3=}$ Katılımcıların itibar yönetimi algıları ile personel güçlendirme algıları birbirini etkiler mi?” incelendiğinde ise;

-İtibar katsayısı ve personel güçlendirme ölçekleri arasında pozitif yönde anlamlı bir ilişki olduğu sonucuna ulaşılmıştır.

Araştırmada, ilköğretim mezunlarının itibar katsayısı ölçeği toplamından, "finansal performans" alt boyutlarından daha düşük puan aldığı görülmüştür. Oysa Güneş (2016: 42)'in konut sektöründe faaliyet gösteren bir örgütte yaptığg araştırmada "finansal performans” alt boyutu yüksek düzeyde çıkmıştır. Bu durumun sektör farklılığından kaynakladığı düşünülmektedir.

Genel idari hizmetler kadrosu dışında kalan birimlerde çalışanların itibar katsayısı ölçeğinden, Valilik iç birimlerinde çalışanların itibar katsayısı ve personel güçlendirme ölçeklerinden daha yüksek puan ortalamasına sahip oldukları belirlenmiştir. Bu durumun, adı geçen birimlerde çalışanların birebir halkla ilişski içerisinde bulunmaması ve daha çok genel idari hizmet çalışanlarını destekleyici faaliyette bulunmalarından kaynaklandığ 1 düşünülmektedir. Benzer şekilde, Candan vd. (2015: 260)'nin çalışmasında da kadro türü farklılıklarının personel güçlendirme algısını etkilediği sonucuna varılmıştır. Ayrıca Kurtuluş (2018: 92) ise bir eğitim kurumundaki araştırmasında kıdemli işgörenlerin kıdemsiz işgörenlere nazaran kurumsal itibar algılarının daha yüksek olduğunu tespit etmiştir. Bu araştırma bulgusunda ise durum tersi yöndedir. Bu durumun nedeni eğitim kurumlarında itibar algısının farklılaştığı yönde yorumlanabilir. 
İtibar katsayısı ölçeği ve personel güçlendirme ölçeklerinden alınan puan ortalamalarının yaş ve iş tecrübesinden etkilenmediği, eğitim durumu ve kadro türünün ise personel güçlendirme ölçeğinden alınan puanları etkilemediği sonucuna ulaşılmıştır. Candan vd. (2015: 260)'nin personel güçlendirme ile ilgili araştırmalarında; katılımcıların cinsiyet, yaş, hizmet süresi ve eğitim durumuna göre personel güçlendirme algısının etkilenmediğini bildirmişlerdir. Yine Gül ve Avcı (2018: 67) araştırmalarında, itibar katsayısı algısının yaş farklılıklarından etkilenmediği sonucuna varmışlardır. Bu bulgular da araştırma sonucunu desteklemektedir.

$\mathrm{Bu}$ araştırmada, itibar katsayısı ve personel güçlendirme ölçeğinden alınan puan ortalamalarının cinsiyetten etkilenmediği belirlenmiştir. Ancak, Alnıçık vd. (2010: 105) araştırmalarında ise kurumsal itibar bileşenlerinin her birinde erkek katılımcıların algıladığ 1 önem düzeyinin kadın katılımcılara nazaran daha düşük düzeyde olduğu sonucuna varmıştırlar. Bu durum örneklemin aktif çalışan işgücü ile halen öğrenci olarak ileride işgücüne katılacak kesimler arasındaki algı farklılığından kaynaklanabilir.

Medeni durumu bekar olanların itibar katsayısı ölçeği toplamı, "ürün-hizmet kalitesi", "vizyon ve liderlik" alt boyutlarından daha yüksek puan ortalamasına sahip olduğu ve farkın istatistiksel olarak anlamlı olduğu $(\mathrm{p}<0.05)$ belirlenmiştir. Ancak medeni durum değişkeni, personel güçlendirme ölçeğinden alınan puan ortalamalarını etkilememektedir $(\mathrm{p}>0.05)$.

Bu araştırmada itibar katsayısı ve personel güçlendirme ölçeğinden alınan puanlar arasında pozitif yönde ilişki bulunmuştur. İtibar katsayısı ölçeğinden alınan puanlar yükseldikçe personel güçlendirme ölçeğinden alınan puanlar da yükselmekte idi. Benzer şekilde Bedük ve Tambay (2014: 334-335) tarafından bankacılık sektöründe personel güçlendirme ve itibar yönetimi kavramlarını birlikte inceleyen araştırmada; personel güçlendirme ölçek puanındaki bir birimlik artışın itibar yönetimi ölçek puanında 0,81 birimlik artışa neden olduğu görülmüş ve bu sonucun bankaların personel güçlendirme faaliyetlerine verdikleri önemin, aynı zamanda itibar yönetimlerini de olumlu etkileyeceğini ve çarpan etkisiyle artı bir değer yaratacağı ifade edilmiştir. Bunun yanında otelcilik sektöründe personel güçlendirmenin iş tatmini üzerinde olumlu bir etkisinin olduğu (Özer vd., 2015: 114), örgütlerde kurumsal itibarın örgütsel performansla pozitif bir ilişkisi olduğu (Aktaş, 2014: 84) ve tüketicilerin bir şirketin sosyal medya faaliyetindeki katılım düzeyinin kurumsal itibar algıları ile pozitif ilişkili olduğu (Dijkmans vd., 2015: 64), sosyal medyayı aktif kullanmanın, o örgütün imajına ve devamında itibarına olumlu katkılar sağlayacağı (Özer, 2016: 118-119), kurumsal itibardan söz edilebilmesi için müşteri memnuniyetinin ön planda tutulması gerektiği (Su vd., 2016: 3265) sonuçlarına ulaşan araştırmalar mevcuttur. Son olarak Men ve Stacks (2013: 183) araştırmalarında dönüşümcü liderlerin, astlarını güçlendirmeleri sayesinde sadece doğrudan değil dolaylı olarak da kurumsal itibar algısının güçlenmesine olumlu yönde katkı yaptığını ortaya koymuşlardır.

Tüm bu sonuçlar dikkate alındığında aşağıdaki önerilerde bulunulabilir: 
-Kamu kurumlarında;

-İlköğretim mezunu düzeyi haricindeki ve medeni durumu evli olan kamu personelinin kurumsal itibar algılarının oluşturulmasına yönelik eğitim ve farkındalık faaliyetlerinin yapilması,

-İSKUR personelinin ürün-hizmet kalitesi boyutunda kurumlarını yetersiz görmelerinin nedenlerinin araştırılması ve varsa gerekli iyileştirmelerin yapılabilmesi için somut önerilerin geliştirilmesi,

-Araştırma sonuçlarının yaygınlaştırılması ve coğrafyalar arası olası değişikliklerin saptanabilmesi adına benzer araştırmaların farklı ülke, il ve kurumlarda yapılarak sonuçlarının karşılaştırılmalı olarak incelenmesi önerilmektedir. 


\section{KAYNAKÇA}

Abratt, Russell ve Kleyn, Nicola (2012). Corporate Identity, Corporate Branding and Corporate Reputations: Reconciliation and Integration, European Journal of Marketing, 46(7/8), S-1048-1063.

Akçakaya, Murat (2010). Örgütlerde Uygulanan Personel Güçlendirme Yöntemleri: Türk Kamu Yönetiminde Personel Güçlendirme, Karadeniz Araştırmaları Dergisi, Sayı: 25, S-145-174.

Aktaş, Kadir (2014). İtibar Yönetimi, İş Memnuniyeti ve Örgütsel Performans Arasındaki İlişkinin Analizi: Sağlık Sektöründe bir Uygulama, Yayımlanmamış Yüksek Lisans Tezi, Gediz Üniversitesi Sosyal Bilimler Enstitüsü, Konya.

Alnıaçık, Esra, Alnıaçık, Ümit ve Genç, Nurullah (2010). Kurumsal İtibar Bileşenlerinin Algılanan Önemi Demografik Özelliklerinden Etkilenmekte midir? Balıkesir Üniversitesi. Sosyal Bilimler Enstitüsü Dergisi. 13(23). S-93-114.

Arslan, Mustafa ve Karacaoğlu, Korhan (2018). Kamu Görevlilerinin Kurumsal İtibar Algılarının Kamu Hizmet Motivasyonlarına Etkisi: Nevşehir İlçe Belediyeleri Üzerinde Bir Araştırma, Organizasyon ve Yönetim Bilimleri Dergisi, 10(1). S-14-29.

Barnett, Michael L., Jermier, John M. ve Lafferty, Barbara A. (2006). Corporate Reputation: The Definitional Landscape, Corporate Reputation Review, 9( 1). S-26-38.

Bayram, Ayhan, Güler, Seyhan Bilir ve Akın, Yasemin Koldere (2016). Mahalli İdarelerde İtibar Yönetimi. Süleyman Demirel Üniversitesi İktisadi ve İdari Bilimler Fakültesi Dergisi. 21(1). S-251-274.

Bedük, Aykut ve Tambay, Ahmet (2014). Personel Güçlendirme (Empowerment) ve İtibar Yönetimi İlişkisi: Bankacılık Sektöründe Bir Alan Çalışması. Akademik Sosyal Araştırmalar Dergisi, Yıl: 2, Sayı: 8, S-319-338.

Bedük, Aykut (2012). Karşılaştırmalı İşletme-Yönetim Terimleri Sözlüğü. Nobel Yayınları. 3. Basım. ISBN: 978975-6266-33-5. S-108-109.

Boon, Jan, Verhoest, Koen ve Wynen, Jan (2019). What Determines the Audiences that Public Service Organisations Target For Reputation Management?, Policy \& Politics. $x x(x x)$. S-1-20.

Bowen, David E. ve Lawler III, Edward E. (1992). The Empowerment of Service Workers: What, Why, How, and When, Sloan Management Review, 33(3), S-31-39.

Butler, Alice, Schafran, Alex, ve Carpenter, Georgina (2018). What Does It Mean When People Call a Place a Shithole? Understanding a Discourse of Denigration in the United Kingdom and the Republic of Ireland. Transactions of the Institute of British Geographers, 43(3). S-496-510. doi:10.1111/tran.12247

Candan, Hakan, Canbolat, Mehmet Ali ve Öksüz, Yavuz Selim (2016). Personel Güçlendirmenin Örgütsel Bağlılık Üzerine Etkisi: Bir Kamu Kurumunda Araştırma. Kahramanmaraş Sütçü İmam Üniversitesi İktisadi ve İdari Bilimler Fakültesi Dergisi. 5(2) S-255-266.

Cengiz, Ekrem ve Kırkbir, Fazıl (2007). Yerel Halk Tarafından Algılanan Toplam Turizm Etkisi ile Turizm Desteği Arasındaki İlişkiye Yönelik Yapısal Bir Model Önerisi, Anadolu Üniversitesi Sosyal Bilimler Dergisi, 7(1), S-19-37.

Chang, Li-Chun ve Liu, Chieh-Hsing (2008). Employee empowerment, Innovative Behavior and Job Productivity of Public Health Nurses: A Cross-Sectional Questionnaire Survey. International Journal of Nursing Studie., 45. S-1442-1448. 
Christensen, Tom, Åse Gornitzka, ve Francisco O. Ramirez (2019) "Reputation Management, Social Embeddedness, and Rationalization of Universities." In: Universities as Agencies. Palgrave Macmillan, Cham, S-3-39.

Chun, Rosa (2005). Corporate Reputation: Meaning and Measurement. International Journal of Management Reviews, 7(2). S-91-109.

Hales, Colin ve Klidas, Antonis (1998). Empowerment in Five-Starhotels: Choice, Voice or Rhetoric? International Journal of Contemporary Hospitality Management, 10(3), S-88-95.

Conger, Jay A. ve Kanungo, Rabindra N. (1988). The Empowerment Process: Integrating Theory and Practice. The Academy of Management Review, 13(3). S- 471-482.

Cunningham, Ian, Hyman, Jeff ve Baldry, Chris (1996). Empowerment: the power to do what?, Industrial Relations Journal, 27(2), S-143-154.

Çınaroğlu, Songül ve Şahin, Bayram (2013). Özel ve Kamu Hastanelerinin Algılanan Kurumsal İtibar ve İmaj Açısından Karşılaştırılması. Uluslararası Yönetim İktisat ve İşletme Dergisi 9(18). S-283-298.

Dijkmans, Corné, Kerkhof, Peter ve Beukeboom, Camiel J. (2015). A Stage to Engage: Social Media Use and Corporate Reputation. Tourism Management. 47. S-58-67.

Dowling, Grahame R. (2004). Corporate Reputations: Should You Compete on Yours? California Management Review. 16(3). S-18-36.

Dowling, Grahame ve Moran, Peter (2012). Corporate Reputations: Built in or Bolted on?, California Management Review, 54(2). S-25-42.

Eğilmez, Özüm (2017). Kurumsal İtibar Yönetimi: Tepe Yöneticisinin Güvenilirliğinin Kurumsal İtibar ve Çalışan Olma Niyetine Etkisi, Yayımlanmamış Doktora Tezi, Anadolu Üniversitesi Sosyal Bilimler Enstitüsü, Eskişehir.

Ergenç, Emre (2010). Kurumsal İtibar Yönetiminde Liderliğin Rolü Üzerine Bir Araştırma, Yayımlanmamış Yüksek Lisans Tezi, Marmara Üniversitesi Sosyal Bilimler Enstitüsü, İstanbul.

Ertenü, Behice (2008). The Role of Psychological Empowerment Between Managerial Practices and Organizational Citizenship Behavior, Unreleased PhD Thesis, Marmara Üniversitesi Sosyal Bilimler Enstitüsü, İstanbul.

Fombrun, Charles J, Gardberg, Naomi A. ve Sever, Joy M. (2000). The Reputation Quotient ${ }^{\mathrm{SM}}$ : A MultiStakeholder Measure of Corporate Reputation. The Journal of Brand Management. 7(4). S-241-255.

Gössling, Stefan, Zeiss, Harald, Hall, C. Michael, Martin-Rios, Carlos, Ram, Yael ve Grøtte, Ivar-Petter (2019). A Cross-Country Comparison of Accommodation Manager Perspectives on Online Review Manipulation. Current Issues in Tourism, (22)14, Doi: 10.1080/13683500.2018.1455171

Griffin, Ricky, W., Phillips, Jean, M., ve Gully Stanley, M. (2015). Organizational Behavior: Managing People and Organizations, Twelfth Edition, Cengage Learning, S-469-470.

Gül, Hasan ve Avc1, Murat (2018). Kurumsal İtibarın Kariyer Yönetimi Üzerindeki Etkileri: KTMÜ Örneği. KMÜ Sosyal ve Ekonomik Araştırmalar Dergisi. 20(34) S-53-69.

Güneş, İpek Suat (2016) Kurumsal İtibar Yönetimi, Yayımlanmamış Yüksek Lisans Tezi, Bahçeșehir Üniversitesi 
Sosyal Bilimler Enstitüsü, İstanbul.

Helm, Sabrina (2007). “One Reputation or Many?: Comparing Stakeholders' Perceptions of Corporate Reputation". Corporate Communications: An International Journal, 12(3. S-238-254, https://doi. org/10.1108/13563280710776842.

Highhouse, Scott, Brooks, Margaret, E. ve Gregarus, Gary (2009). An Organizational Impression Management Perspective on the Formation of Corporate Reputations, Journal of Management, 35(6), S-1481-1493. Doi: 10.1177/0149206309348788.

Işık, Metin, Çiçek, Berat ve Almalı, Vedat (2016). Üniversitelerin İç Paydaşlarının Kurumsal İtibar Algısını Ölçmeye Yönelik Bir Araştırma, Bitlis Eren Üniversitesi Sosyal Bilimler Enstitüsü Dergisi 5(1). S-163-180.

Karahan, Atila (2009). İnsan Kaynaklarının Geliştirilmesine Katkısı Açısından Personel Güçlendirme Yaklaşımı: Afyon Kocatepe Üniversitesi Hastanesi Örneği, Celal Bayar Üniversitesi S.B.E. Dergisi. 7(1). S-95-114.

Karatepe, Selma (2008). İtibar Yönetimi: Halkla İlişkilerde Güven Yaratma, Elektronik Sosyal Bilimler Dergisi. 7(23). S-77-97.

Kızıl, Seda ve Naktiyok, Atılhan (2019). Yöneticilerin Stratejik Liderlik Davranışlarının Kurumsal İtibar Algısı Üzerine Etkisinde Kurumsal Sosyal Sorumluluğun (KSS) Rolü, Istanbul Business Research, 48(1). S-64-83.

Kurtuluş, Osman (2018). Liselerde Görev Yapan Öğretmenlerin Kurumsal İtibara İlişkin Görüşleri. Yayımlanmamış Yüksek Lisans Tezi, Harran Üniversitesi Sosyal Bilimler Enstitüsü, Şanlıurfa.

Köksal, Selin (2011). Müşterilerin Yeşil (Çevreci) İ̧sletmelere Yönelik Kurumsal İtibar Algısı Üzerine Bir Araştırma. Yayımlanmamış Yüksek Lisans Tezi, Çukurova Üniversitesi Sosyal Bilimler Enstitüsü, Adana.

Men, Linjuan Rita ve Stacks, Don W. (2013). The Impact of Leadership Style and Employee Empowerment on Perceived Organizational Reputation. Journal of Communication Management, 17(2). S-171-192. https:// doi.org/10.1108/13632541311318765.

Martin, Graeme ve Hetrick, Susan (2006). Corporate Reputations, Branding and People Management: A Strategic Approach to HR, Published by Elsiver. ISBN: 0-7506-6950-0. S-21.

Owens, Ryan J. ve Wohlfarth, Patrick, C. (2019). The Influence of Home-State Reputation and Public Opinion on Federal Circuit Court Judges. Journal of Law and Courts 7(2). S-187-214.

Öksüz, Yavuz Selim (2010). Kamu Sektöründeki İnsan Kaynakları Yönetiminde Personel Güçlendirme Yaklaşımının Uygulanabilirliği, Yayımlanmamış Yüksek Lisans Tezi, Selçuk Üniversitesi Sosyal Bilimler Enstitüsü, Konya.

Özaksu, Özgür (2006). İnsan Kaynakları Geliştirmede Personel Güçlendirme Yaklaşımı ve Bir Saha Araştırması. Yayımlanmamış Yüksek Lisans Tezi, İstanbul Üniversitesi Sosyal Bilimler Enstitüsü, İstanbul.

Özer, Cevat Sercan (2016). Sosyal Medyayı Kullanan Kurumların İtibar Yönetimine İlişkin Y Kuşağııın Algısı. Yayımlanmamış Yüksek Lisans Tezi, Ege Üniversitesi Sosyal Bilimler Enstitüsü, İzmir.

Özer, K. Ozan, Ergün, Özgür ve Okatan, Tuncer (2015). Personel Güçlendirmenin İş Tatmini Üzerindeki Etkileri: İstanbul Otelcilik Sektörü Araştırması. Kastamonu Üniversitesi İktisadi ve İdari Bilimler Fakültesi Dergisi. Say1: 6. S-104-115.

Pelit, Elbeyi (2011). Güçlendirmede Yönetici ve İşgören Algılamalarının Karşılaştırılması. Selçuk Üniversitesi 
Sosyal Bilimler Enstitüsü Dergisi. 25. S-209-225.

Pradhan, Preethi, Kamlanabhan, TJ, Thulasiraj, RD ve Muraleedharan, VR (2014). Employee Empowerment. Journal of Multidisciplinary Research in Healthcare. 1(1), S-53-62.

Su, Lujun, Swanson, Scott R., Chinchanachokchai, Sydney, Hsu, Maxwell K. ve Chen Xiaohong (2016). Reputation and intentions: The Role of Satisfaction, Identification, and Commitment, Journal of Business Research, 69. S-3261-3269.

Şenel, Özlem (2006). Personel Güçlendirmenin Örgüt Kültürüne Etkisi. Yayımlanmamış Yüksek Lisans Tezi, Dokuz Eylül Üniversitesi Sosyal Bilimler Enstitüsü, İzmir.

Tekin, Yasemin ve Köksal, Can Deniz (2012). Otel İşletmelerinde Personeli Güçlendirme Uygulamaları: Antalya' da Beş Yıldızlı Konaklama İşletmelerinde Bir Araştırma, Journal of Yasar University, 25(7), S-4241-4267.

Tokatlı, Mehmet (2015). Sosyal Medya’ da İtibar Yönetimi: Üniversiteler Üzerine Bir Araştırma, Yayımlanmamış Yüksek Lisans Tezi, Ege Üniversitesi Sosyal Bilimler Enstitüsü, İzmir.

Türk, Sezai ve Güven, Ahmet (2007). Yeni Başlayanlar İçin Halkla İlişkiler, Ankara: Gazi Kitabevi.

Usta, Murat (2006). Örgüt Kültüründe Halkla İlişkiler ve İtibar Yönetimi Ege Akdeniz Bölgelerindeki Turizm İşletmeleri Örneği, Yayımlanmamış Yüksek Lisans Tezi, Dokuz Eylül Üniversitesi, Sosyal Bilimler Enstitüsü, İzmir.

Wang, David Han-Min, Yu, Tiffany Hui-Kuang ve Chiang, Chia-Hsin (2016). Exploring the Value Relevance of Corporate Reputation: A Fuzzy-Set Qualitative Comparative Analysis. Journal of Business Research. 69. P-1329-1332.

Yağcıŏlu, Ayşe (2012). İtibar Yönetimi Kavramının İşlevselliği ve İtibar Unsurlarının Birbiriyle İlişkisi: Otel İşletmeleri Açısından Bir Uygulama, Yayımlanmamış Yüksek Lisans Tezi, Balıkesir Üniversitesi Sosyal Bilimler Enstitüsü, Balıkesir.

Yurt, İrfan (2012). Kurumsal İtibar Yönetimi Algısının Örgütsel Bağllık Üzerindeki Etkisi: Düzce Üniversitesi Örneği. Yayımlanmamış Yüksek Lisans Tezi, Düzce Üniversitesi Sosyal Bilimler Enstitüsü. Düzce.

Yüce, Alpaslan ve Taşdemir, N. Havva (2019). Kurumsal İtibarı Sağlamada Sosyal Medyanın Etkin Rolü: Kurumsal İtibar Lideri Firmaların Sosyal Medya Paylaşımlarının İncelenmesi, Uluslararası Sosyal Araştırmalar Dergisi, 12(63). S-1185-1196. 
TROYACADEMY

International Journal of Social Sciences 